\title{
Критичен анализ на биполярна радиочестотна термотерапия, използвана за редукция на мекото небце и носните конхи при хабитуално хъркане
}

\author{
М. Милков ${ }^{1}$, Ив. Ценев ${ }^{2}$, Д. Марев ${ }^{3}$, Цв. Тончев ${ }^{3}$ \\ ${ }^{1}$ АСМПМЦ "Св. Петка" - Варна \\ гУМБАЛ "Царица Йоанна" - София \\ ЗУМБАЛ "Св. Марина" - Варна
}

\begin{abstract}
The aim of this study is to estimate the percentage of success of the device of Olympus - Celon which uses the principle of bipolar radiofrequency induced thermotherapy (RFITT). The bipolar applicators are introduced into the tissuc, which must be treated. These applicators are conformed to the anatomical and physiological characteristics of the treated body regions. The radiofrequency current is generated between the couple of clectrodes which are positioned in the applicator tip. Automatic dosimetry control ensures an optimal, soft tissue coagulation. Patients and methods: 56 patients with snoring were treated. In 18 patients the volume of the nasal conchac was reduced and in 38 cases the soft palate was treated by RFITT

Results: In 40 cases decrease of snoring was detected and in 15 patients the snoring stopped definitely after the treatment.

Conclusions: The reduction of soft palate and nasal conchae using bipolar RFITT of Olympus-Celon is cases of snoring is effective and inexpensive procedure. However, we would like to underline the importance of the thorough diagnostics of snoring.

Key words: snoring, bipolar electrodes, radiofrequency volume reduction, sleep apnoe syndrome
\end{abstract}

Резюме

Цел: Цел на настояцата разработка с да сс оцени количествсно процентът на успевасмост на модсл, при който се използва принципът на биполярната радиочестотна термотерапия (RFITT) от фирмата Olympus-Celon. Биголярните апликатори се въвеждат в тьканта, която трябва да бъде третирана. Тези апликатори са съобразени с анатомично-физиологичните особености на третираните области на тялото. Радиочестотният ток се генерира между двойката електроди, вградени във върха на сондата. Генсраторьт на фирмата Olympus-Celon има автоматичен дозиметричсн контрој, който осигурява оІтимална коагулация на тъканите.

Методи и пациенти: Третирани са били 56 пациенти с първично хърканс. Интснзивността на хъркането е била оценявана субективно с цифрова аналогова скала (от $0=$ пациентьт не хърка, до 4 = пациентьт продылжава да хърка бсз промяна)

\section{Въведение}

Радиочестотата отдавна се използва успешно за термична редукция на тъканите. За това се предлагат както монополярни, така и биполярни системи. ІІрицелни лезии са уплътнения на ушната мида (1-5), уплътняване и втвърдяване на мекото небце $(1,13,23)$, както и редукция на основата на езика $(6,23)$.

Оро-лингвалната радио- и високочестотна апликация при хъркане и SAS е относително нов метод (Powell и сътрудници 1997 г.), който се основава на коагулационна техника с термично обратно свързване в монополярен модус. Powell и сьтрудници, а по-късно и други автори $(7,8,22,24,25,32)$ могат да се похвалят с добри постижения. Но в литературата са описани и усложнения в областта на основата на езика $(6,7$, 8,32 ). Недостатъците на метода (голяма продължителност на апликацията, разходи за интервенцията, монополярен модус) са определящите фактори за развиването на нова собствена теоретична концепция, използвайки оригинални биполярни елгктроди.

В България за първи път РЧТТ е въведена от проф. И. Ценев в МБАЈI "Царица Йоанна" през 2001 г. с апаратурата за RFITT Celon.

Съобразените със специфичната анатомия електроди, които се използват, са един модерен радиочестотен апарат (Olympus-Celon изображение 4).

Въведеният от автора метод на биполярна радиочестотна редукция на обема $(1,9,10,23)$ се съобразява с разработките върху проблема на радиочестотното третиране на хъркането. Същевременно се базира и 
преди операцията и последователно - 6 месеца и 1 година след операцията.

При 18 пациенти е редуциран обемът на носните конхи, а при 38 се е провела радиочестотна термотерапия на мекото небце. Резултати: При 40 от пациентите е било постигнато намаление на хъркането. При 15 според партньора хъркането с спряло напълно след лечението.

Заключение: Редукция на мекото небце и носните конхи по метода на биполярната радиочестотна термотерапия на Olympus-Celon успешна методика за лечението на социално значимо хъркане, ефикасна и финансово ефсктивна. С този метод терапията на хъркането е значително усъвършенствана, но ние искаме да подчертаем и необходимостта от задьлбочена диагностика на хъркането.

Ключови думи: хъркане, биполярни електроди, радиочестотна редукция на обема, синдром на сънна апнея. на дългогодишния опит с биполярна високо, респ. радиочестотна редукция на обема на носните конхи (за лечение на вазомоторен ринит и хъркане).

\section{Пациенти и методи}

За периода от септември 2006 г. до март 2008 г. са били амбулаторно третирани с метода на RFITT-система 51 пациенти с първично хъркане (без инсомния без сомнолентност) и 5 пациенти със съмнение за синдром на сънна апнея.

Боди-мас-индексьт (BMI) е бил оценен като недостатък при 44 пациенти, които не са били приети за оперативно лечение. При 20 пациенти е открито изкривяване на септума на носа и едемни носни конхи. При двама пациенти е установена хиперплазия на тонзилите.

Пациенти са били оперирани амбулаторно с местна анестезия. Като анестетик е бил използван $2 \%$ Lidocain, 1:200 000 шпрей Lidocain.

На някои пациенти са били предписани аналгетици и съдържащ кортизон назален шпрей за орално приложение. Превантивна постоперативна антибиотична профилактика е провеждана само при пациенти с проблеми (5-6). При 8 пациенти са били коригирани преди РЧ-терапия девиации на носната преграда. След апликацията на двама пациенти е направена увулектомия поради много дълга увула.

\section{Диагностични критерии и изключващи критерии}

Пациентите са били обичайно с рино и/или веларна патология хипертрофии, респ. обструкции (табл. 3). Поради липса на диагностична апаратура не са били изключвани тежки форми на SAS (симптоми на хипоксемия, усложнения). Пациенти със заболявания като хипертония, диабет, кардиоваскуларни и кардио -пулмонални заболявания, диатези не са били подлагани на RFITT. Основавайки се на разпределението на синдрома на обструктивна сънна апнея (COCA) по степен на тежест досега не се използват и класификациите на Simmons (33), Viner et al. (34), Tami et al. (18), Friberg et al. (13). Избирателно са били наблюдавани за хипертрофия на носните конхи и уголемяване и спадане на мекото небце данните от кардиореспираторните параметри ("Respiratory Sleep Recording" (13), "оценка на риска" (33). В тази група не влизат пациенти с високостепенно затлъстяване, прием на седатива, алкохолна и никотинова консумация.

На всички пациенти предоперативно са били правени рентгенови изследвания (оглед на орофаринкса, палпация на велума, назоендоскопия, трансназална назофарингеална ендоскопия в седнало положение, фаринголарингоскопия, на някои пациенти натривка от гърлото, рентгеново изследване). 


\section{Критерии за ощенка}

Успехът от апликацията на RFITT е бил оценяван по ендоскопски параметри (латеро-латерална и/или кранио-каудална, респ. антеро-постериорно разширяване на фарингеалното пространство, повдигане на увулата, вентрална проекция на велума, уплътняване на тъканта на небцето, намаляване на обема на мекото небце, носните конхи). Респективно обективни параклинични параметри (риноманометрия, сомнография).

Анатомичните отношения на орофаринкса са били документирани и анализирани количествено преи постоперативно чрез трансназална и трансорална видеоендоскопия.

Интензитетьт на хъркането (сила на звука) е бил оценяван от пациентите и партньорите им пре- и постоперативно чрез цифрова аналогова скала (NAS) - таблица 5.

Промяната на плътността на хъркане (продължителност и честота), респ. шумове е била научена от самите пациенти в пряк разговор.

\section{Резултати}

Не са били наблюдавани впечатляващи локални промени при пациентите в тази група. Проведените след 4-6 месеца контролни изследвания и визуална оценка са дали резултати: разширение на назовералната и/или орофарингеалната зона (стеснение) с 3 до 4 мм.

В $80 \%$ от случаите е било съобщено за редукция на хъркането (NAS score) постоперативно - 15 от 56 от пациентите не са хъркали след интервенцията, 10 от 36 са хъркали по-тихо или само понякога. Запитването показва намаление на интензитета на хъркане при 11 от 56.

Постоперативният толеранс е бил много добър. Не са настыпили никакви усложнения. Наблюдаван е бил умерен постоянен за 1 до 3 дни едем на мекото небце. Съобщено е било и за леки смущения при прегльщане.

\section{Дискусия}

\section{Анатомични взаимоотнасяния на хъркането и използвания метод}

Лигавицата на общия носен ход образува, особено в областта на долната носна конха, зона със силно изразени венозни, кавернозни пространства (описани от Zuckerkandl (18).

При нормално вдишване количеството на инхалирания въздух зависи в около $2 / 3$ от вентилната функция на носа и в около $1 / 3$ от вазомоторната активност на носните конхи. При нормално издишване участието на важните механизми е приблизително по равно (27). Тъй като главата на долната конха изпъква в равнината на носните клапи, носните конхи участват съществено в съпротивлението на носа (22). Вазомоториката на носните конхи, респ. капацитетът на напълване на съдовете от оточната тъкан може да бъде повлиян от редица многобройни различни физиологични фактори (положение, цикъл на носа) или патологични фактори $(20,21,22)$. Доста отдавна се дискутира, понякога и ожесточено, връзката между пермеабилитета на носа и хъркането (7, 28). Обструкцията на носа не предизвиква хриптене, но умерените ограничения (девиация на носната преграда, хипертрофия на конхите) го благоприятстват и усилват (17). Доброто носно дишане е предпоставка за успеха на обемната редукция на меките части на небцето. Авторите, които съобщават за комбинирано РЧ-третиране на велум и носни конхи (корекции на септума) $(35,15,31)$, докладват за редукция на шумовете от хъркане с около $40 \%$ (7).

Почти всички изследвани в тази група пациенти са показали при рино-ендоскопия турбинална хипертрофия. Риноманометрично е потвърдено само в 50\% от случаите намаление на въздушния пасаж през носа. Това се обяснява със силно изразената лабилност на пълнене на оточната тъкан, която може да варира при един и същи човек през различните часове (36). В специализираната литература се дискутира, че не винаги се потвърждават намаленията на носния въздушен пасаж, особено ако и в легнало положение има ограничения (37). Модифицираната биполярна игла по Binner (CelonOlympus) осигурява заедно с RFITT-генератора оптимален баланс между времето на апликация, като автоматично отчита според съпротивлението на тъканите и времето за апликация (средно 6-9 сек.), изискваната ниска интензивност (8-9 вата), както и ограничената минимална термична дифузия в околните тькани.

Една апликация по протежение на носните конхи е достатъчна.

Детайлните познания за анатомията, физиологията и хистоморфологията на велума и увулата са от решаващо значение за успеха на хирургията на хъркането $(20,21,33)$.

Мекото небце и велум палатинум са една мускулноапоневрозна структура, без анатомична равнина на цепене, която да затруднява отпрепарирането между мускулните и сухожилни слоеве. Вследствие на това и на базата на липсваща подлежаща хрущялна или костна структура може да възникне хипертрофия, кървене и едем в тази 
област, който да доведе до стеснение на лумена на фаринкса и до нарушения на дишането, респ. хъркане $(22,27,28,30)$.

Наблюдаваната ендоскопски тенденция за колабиране поради декубитус дорзалис на велума ("sloping downward"), както и хипертрофията на краниопостериорните веларни сегменти може да бъде отговорна за своеобразна "небна клапа" и да уврежда не само оралното, но и назално, постхоанално дишане.

Увулата (m. uvulae) играе важна роля във фонацията $(12,14,21,22)$. Нейната контракция е преамбюл за всяко веларно движение. Мускулът на увулата стабилизира останалите 4 мускулни двойки в областта на небцето и скъсява, повдига, втвърдява, ретрахира и ретропулсира велума $(14,17,18,19)$. При твърде агресивно третиране на увулата съществува риск от възможна ринофония и назален алиментарен рефлукс $(12,14,19,24)$. Нетретирането на увулата с РЧ се базира също на проучвания, че дегенерацията на мастната и съединителна тъкан на мускулните структури води до дестабилизация на увулата (12). Предизвиканата цикатризация и втвърдяване на съединителната тъкан и колагенните влакна трябва да повдигна достатьчно увулата и да проектира напред велума.

Някои автори споменават за процес на денервация при пациентите със синдром на сънна апнея; така например Woodson чрез електронна микроскопия на увулата (16), Edstroem чрез биопсия на мускули от небцето (11), Friberg и сътр. (13) са наблюдавали при SAS и хъркащи пациенти след мониториране на лазерна доплер-перфузия, комбинирана с електрична периферна нервна стимулация, усилена вазодилатация в областта на меките тъкани на небцето. Тези находки доказват увреда на фарингеалната микроциркулация. Остава открит въпросът за изясняване дали тук по правило се касае за вазомоторни нарушения (подобни на тези в областта на носните конхи), или за т. нар. "неврогенни възпаления" (17) чрез освобождаване на ноцирецепторните дразнители (невропептиди, тахинин, калцитонин и т.н.). Такива хистологични заключения могат да изяснят защо пациентите с макроскопски нормален велум хъркат силно, защо имат смисъл РЧ-апликациите в много равнини и защо характеристиките на велума не са критерий за неуспех (8).

Мускулатурата на горните дихателни пътища е част от дихателната система и се контролира от дихателния центьр в медулата (24). M. levator veli palatini и $\mathrm{m}$. tensor veli palatini втвърдяват и повдигат велума синергично при връзката към задната фарингеална стена, така че тяхното нараняване уврежда фонацията и може да влоши и хъркането $(13,14)$. Хипертрофията на $\mathrm{m}$. palatopharyngeus, който отговаря за повдигането на основата на езика и изтеглянето на небцето назад, играе важна роля в механизма на хъркането (13). Ако велумът трябва да бъде проектиран напред, трябва или да се раздели, или да се увреди. M. palatoglossus образува заедно с m. transversus linguae своеобразен сфинктер, който чрез контракция фрагментира алиментарния болус и изтегля напред небцето. Неговата увреда може да повлияе негативно на очаквания резултат. По-нататък може да се допусне, че $\mathrm{m}$. transversus linguае може да повлияе индиректно негативно на функцията на M. palatoglossus.

Апоневрозата на езика е груба съединителна тъкан между мускулатурата и лигавицата (7). Съществува опасност след дълбоко третиране на основата на езика да възникнат абсцеси $(7,8)$ или хематоми.

Теоретично основата на езика и епиглотиса могат да бъдат изместени, но това вероятно малко влияе на възникването на шумовете при хъркане $(24,28)$. Редукцията на обема само в рамките на лигвалните тозили, без да се нарушава апоневрозата, е била достатъчна при пациентите с хъркане там, където е имала своите индикации.

Критичен анализ към диагностика и лечение на хабитуалното хъркане:

Днес на базата на добрите резултати, които получихме при използването на RFITT, ние очитаме липсата на някои видове апаратура за диагностика на хъркането.

Искаме да предпазим колеги от грешки при обективно отчитане на резултатите си, които до сега не са използвали такава диагностична апаратура.

Не сме провеждали сомнография, радио-видеокинематографични, челюстно-ортопедични изследвания, риноманометрия.

\section{Редукция на обема}

Дискутираните и описани тук терапевтични методи и система RFITT се характеризират със следните свойства:

- Използване на биполярни рестерилизиращи се електроди в паралелна конфигурация, чрез които се постига контролирана триизмерна овална лезия

- Ориентиране на термичните апликации на една виртуална карта на велума, която се съобразява с мускулното разпределение (изобр. 6). В отделни случаи ("нормален велум", субмукозна цепка) тази карта може да стане реална чрез 
ядрено-магнитен-резонансен запис на мускулатурата на небцето и реално да се представи отлагането на мазнини.

- Допълнение към първоначалната представа за концепцията за терапия чрез третиране на задната дъга на небцето.

- Ограничение на третирането в областта на езика, на наличните там лимфатични структури (тонзили) само когато те са хипертрофирали.

\section{Изводи}

Биполярната радиочестотна редукция на обема с помощта на метода с Olympus-Celon се оказа една достъпна, ефикасна и много добре поносима терапия на социално смущаващото явление хъркане.

Първоначалните отчасти добри резултати при синдрома на сънната апнея трябва да бъдат верифицирани в други проспективни проучвания с поголям брой пациенти.

Особенно трябва да се наблегне на селекцията на болни, подходящи за тази терапия, като се включат голям брой изследвания и интердисциплинарни консулти.

Всичко това доказва, че хъркането е един актуален и много труден проблем за лечение.

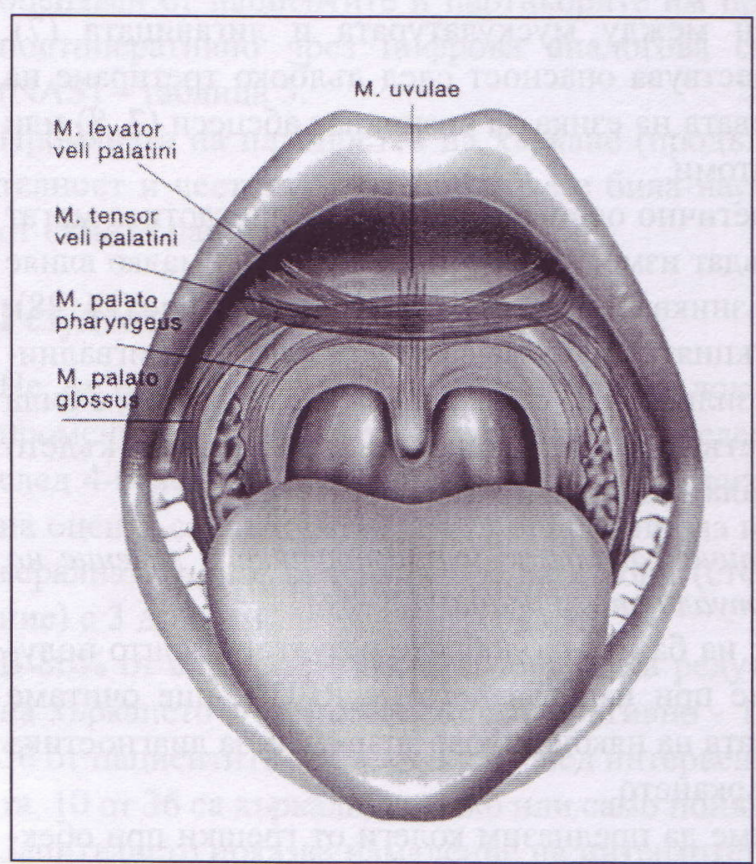

Изображение 1. Меко небце и мускулите: трансмукозна проекция

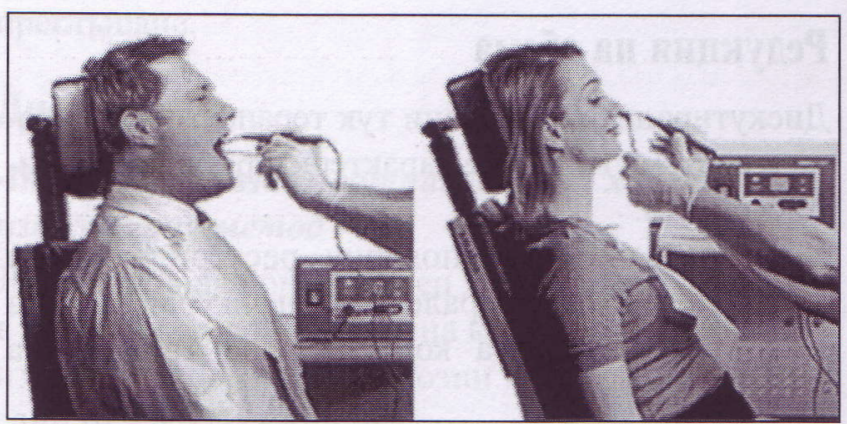

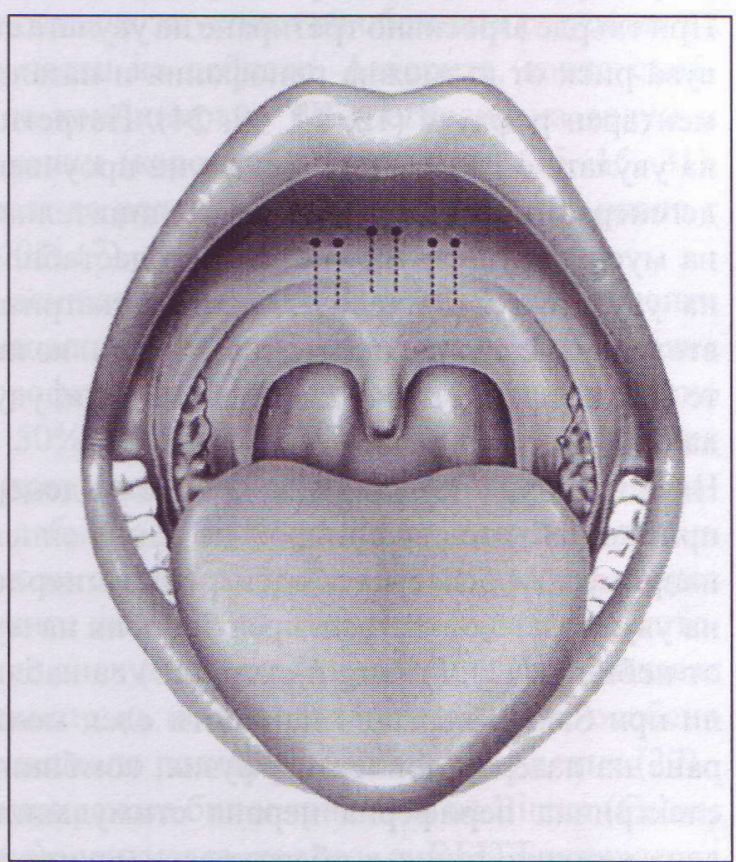

Изображение 2. Биполярна сонда (апликатор) Celon Pro sleep
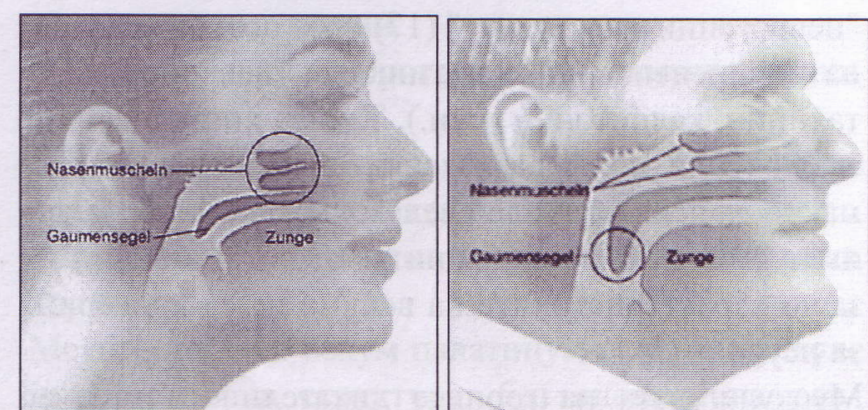

Изображение 3. Места на убождане за веларна апликация в меко небце при сомнопластика 

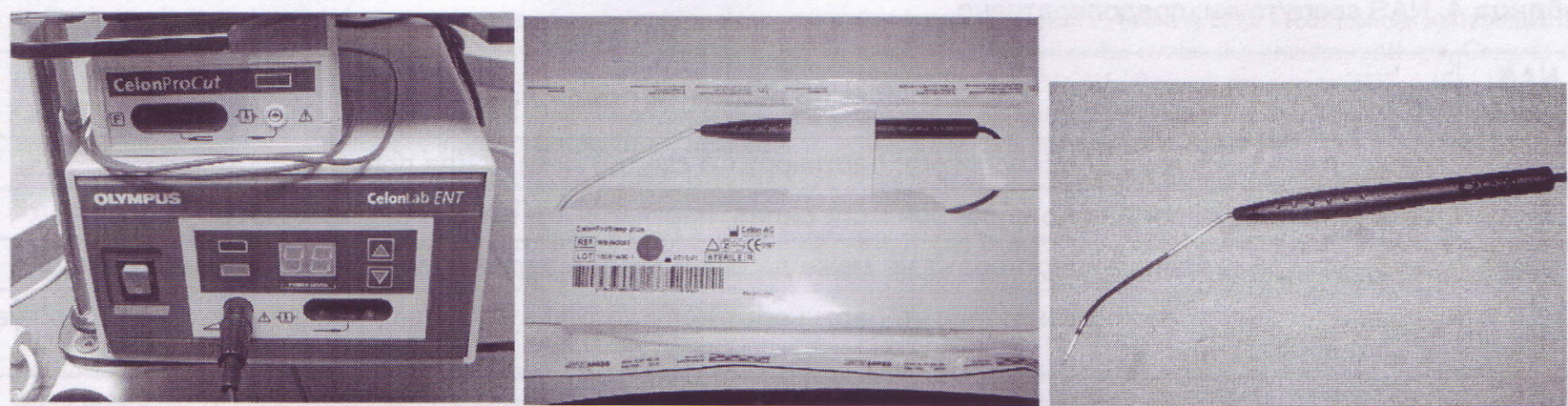

Изображение 4. Celon-Olympus генератор и начин на приложение

\section{Таблица 1}

\begin{tabular}{|l|c|}
\hline Брой пациенти & 56 \\
\hline Възраст (години, средно) & 48 \\
\hline Разпределение по възраст (години) & $32-71$ \\
\hline Пол, относителен дял на мъже \% & 32 \\
\hline Боди мас индекс (осреднен \pm S) & $26.5 \pm 5$ \\
\hline Цифрова аналогова скала (NAS) & -3.3 \\
\hline Брой на РЧ-сеанси & \\
\hline - х 1 в 28 от всички случаи & \\
\hline - х 2 в 20 от всички случаи & \\
\hline - х 3 в 8 от всички случаи & \\
\hline Асоциирано проведени операции & \\
\hline - септопластика и коригиращи операции & \\
\hline - парциална увулектомия & 1 \\
\hline
\end{tabular}

Таблица 2. Индикация за местата на апликация на Рч

\begin{tabular}{|l|c|}
\hline \multicolumn{1}{|c|}{ Място за апликация } & Брой пациенти \\
\hline Носни конхи & 18 \\
\hline Меко небце & 38 \\
\hline
\end{tabular}

Таблица 3. Локална находка при пациентите: предоперативно

\begin{tabular}{|l|c|}
\hline \multicolumn{1}{|c|}{ Находка } & $\begin{array}{c}\text { Брой } \\
\text { пациенти }\end{array}$ \\
\hline Хипертрофия на носни конхи & 18 \\
\hline Хипертрофия на меките части на небцето с намаление на вело-фрарингеалното разстояние & 38 \\
\hline Акцентуирана съдова мрежа на повърхността на велума или стаза & 10 \\
\hline Нормални съотношения на меките части на небцето & 10 \\
\hline Обструктивна девиация на септума (с индикации за операция) & 8 \\
\hline Хипотония на меките части на небцето и шеbьing с намаление на вело-лингвалното разстояние & 7 \\
\hline Твърде дълга увула, контактуваща с езика & 5 \\
\hline Криловидна конфигурация или хипертрофия на задна небна дъга & 4 \\
\hline Хипертрофия на тонзилите на езика, отчасти в контакт с епиглотиса & 4 \\
\hline Увула бифида & 0 \\
\hline
\end{tabular}


Таблица 4. NAS score/точки: предоперативно

\begin{tabular}{|c|c|}
\hline $\begin{array}{l}\text { NAS } \\
\text { score }\end{array}$ & Състояние на пациента преди намесата \\
\hline 1 & пациентът хърка леко и/или понякога; партньорът е смутен леко и/ или понякога \\
\hline 2 & пациентът хърка постоянно и/или понякога силно; партньорът е смутен значително \\
\hline 3 & пациентът хърка силно; партньорът не може да спи и трябва редовно да събужда и движи болния \\
\hline 4 & $\begin{array}{l}\text { пациентът хърка много силно, така че партньорът напуска общата спалня, понякога хъркането се чува } \\
\text { и в съседната стая }\end{array}$ \\
\hline
\end{tabular}

Таблица 5. NAS score/точки: следоперативно

\begin{tabular}{|c|l|}
\hline $\begin{array}{c}\text { NAS } \\
\text { score }\end{array}$ & \multicolumn{1}{|c|}{ Състояние на пациента след намесата } \\
\hline 0 & пациентът не хърка \\
\hline 1 & $\begin{array}{l}\text { пациентът хърка отчетливо/съществено по-тихо и/или само понякога (напр. сутрин наскоро преди ста- } \\
\text { ване), партньорът е смутен само понякога, и то леко, партньорът се е върнал в общата спалня }\end{array}$ \\
\hline 2 & пациентът хърка по-тихо, но все още постоянно, партньорът е смутен, но може да спи в общата стая \\
\hline 3 & $\begin{array}{l}\text { пациентът хърка почти непроменено силно или малко по-тихо, но диша по-добре (намалял е броят на } \\
\text { апноччнте паузи), партньорът е смутен }\end{array}$ \\
\hline 4 & пациентът хърка непроменено силно (както преди) \\
\hline
\end{tabular}

Литература:

1. Цветков В. Радиочестотна редукция на мекото небце при лечение на хъркане и сънна апнея. Българска оториноларингология. Том 2 , брой 3, 2003, 16-19

2. Цветков В., М. Мандажиева, Хр. Златанов. Радиочестотна термоаблация при хипертрофия на носните раковини. Българска оториноларингология. Том 2, брой 3, 2003, 25-27.

3. Hurd LM. Bipolar electrode for elektrocoagulation of the inferior turbinate. Archives of ORL 1931; 441-442

4. Khojada A. Traitement de 1 obstruction nasale par Lelectrocougalation bi-active sous muquese des cornets. Rev. Laryn 1973; 94:1-2

5. Hociota D, Calarusu R. Dimitriu T. Cauterizarea bipolara in practica clinica curneta ORL Otorinolaringologia 1979; 131-136

6. Powell NB, Rilej RW, Troell RJ, Kasey L, Blumen MB. Gullemianault C. Radiofrequency volumetric tissue reduction of the palate in subjects with sleep-disordered breathing: A pilot study. Otolaryngol Head Neck Surg 1999; 120: 656-664

7. Stuck B, Maurer JT, Hormann K. Tongue Base reduction with Radiofrequenz Tissue Ablation: Preliminaly Results after two Treatment Sesions. Sleep and Breathing 2000; 4; 155-162.

8. Stuck B, Starzak K, Verse T, Hormann K, Maurer JT. Complications of Temperatura-controlled Radio-frequency Tissue Reduction for Sleep disordered Breathing. Acta-Otolaryngologika 2003; 123: 532-535

9. Marinesku A Romanitan C. Treatment of ronchopathy with a new bipolar RF application system-clinical results. Oto-Rhino-Laringologia 2001; 3/4: 92-100

10. Marinesskcu A. Treatment of the habitual snoring trough radiofrequency (personal conception). Revista romana de chirurgie rino-sinusala 2003; 1/2 A 195:97-98

11. Edstrom L, Larsson H, Larsson L. Neurogenic effect on the palatopharyngeal muscle in patients with obstructive sleep apnoea: A muscle biopsy study. J Neurol Neurosurg Psych 1992; 55: 916-1022

12. Woodson BT, Carancis JC, Toohill RJ. Histopathologic changes in snoring and obstructive sleep apnea syndrome. Laryngoscope 1991; 101: 1481-1322

13. Friberg D, Gazelius B, Lindblad LE, Nordlander B. Habitual snorers and Sleep Apnoics Have Abnormal Vaskular Reactions of the Soft Palatae Mucosa on Afferent Nerven Stymulation. Laryngoscope 1998; 3: $431-436$
14. Matternich FU, Brusis T, Koebke J, Wenzel S. Untersuchungen zur Histomorphologie und Funktion der Uvula. Laryngo-Rhino-Otol 2000; 79: $465-470$

15. Maurer JT., Hirth K, Hormann K. Bewahrtes und Neues in der Therapie des primaren Schnarchens. Sommno J 2001; 1: 17-23

16. Barbieri M, Pcrottino F, Baricalla F et al. Traitement chirurgical du roflement simple, comparaison des chirurgies velo-turbinales associees. Resume des seances. Congres de la Societe Francaise d ORL2002; A $158: 131$

17. Fairbanks DNF; Effect of nasal surgery on snoring. South Med J 1985; 78: $268-270$

18. Tami AT, Duncan HJ, Pfleger M. Identification of Obstructive Sleep ApneaninPatients Who Snore. Laryngoscope 1998; 3: 508-513

19. Hormann K, Maurer JT, Hirth K. Diagnostik und Therapie des primaren Schnarchens. Laryngo-Rhino-Otol 2000; 4: 822-838

20. Kotecha B. OSAS and snoring: An overview of diagnostic options Istanbul Symposium on Sleep Disordered Breathing Diagnostic options and treatment possibilities in ENT clinic and practice. May 2007

21. Pirsig W.-The role of the nose in sleep-disordered breathing. Istanbul Symposium on Sleep Disordered Breathing Diagnostic options and treatment possibilities in ENT clinic and practice.May 2007

22. MaurerJ.T., K. Hörmann. Polysomnography: A tool for OSAS therapy planning breathing. Istanbul Symposium on Sleep Disordered Breathing Diagnostic options and treatment possibilities in ENT clinic and practice. May 2007

23. Desinger K. Electrosurgery and RFITT: Technology and applications Istanbul Symposium on Sleep Disordered Breathing Diagnostic options and treatment possibilities in ENT clinic and practice. May 2007

24. Yildis F. Minimally invasive multilevel surgery: Tips from the practice Istanbul Symposium on Sleep Disordered Breathing Diagnostic options and treatment possibilities in ENT clinic and practice. May 2007

25. Battagel J, A Johal, B Kotecha. Sleep Nasendoscopy as a predictor of treatment success in snorers using mandibular advancement splints. Journal of Laryngology and Otology, February 2005, Vol 119, $106-$ 112.

26 Battagel J, B Kotecha. Dental side effects of mandibular advancement splint wear in patients who snore. Clinical otolaryngology, Vol 130 , 149-156. 
27. E Chisholm, B Kotecha. Oropharyngeal surgery for obstructive sleep apnoea in CPAP failures. European Archives of Oto-Rhino-Laryngology - Online publication 31 August 2006

28. Khalil H, A. Hannan, B. Kotecha. A prospective clinical study of simultaneous multi-segmental application of bipolar radiofrequency induced thermotherapy for snoring and mild obstructive sleep apnoea. Istanbul Symposium on Sleep Disordered Breathing Diagnostic options and treatment possibilities in ENT clinic and practice. May 2007

30. Maurer J.T., K. Hörmann. Multilevel treatment options in OSAS. Istanbul Symposium on Sleep Disordered Breathing Diagnostic options and treatment possibilities in ENT clinic and practice. May 2007

31. W. Hohenhorst. Drug-Induced Sleep Endoscopy (DISE) in sleep-disordered breathing. Istanbul Symposium on Sleep Disordered Breathing Diagnostic options and treatment possibilities in ENT clinic and practice. May 2007

32. Blumen $\mathrm{Mb}$ et all.Le traitmen du ronflement par radiofrequence avec controle thermique (Somnoplasty). Tolerance et efficacite a court et moyen terme. Annales d orl \& de chirurgie cervico-faciale 2000: 6349358
33. Sambataro G., Lozza P, Scotti A et al. Modifications morphometriques et ultra -structurelles des uvules des grandes ronfluers. Congres de la Societe francaise d ORL. Resume des seaces 2002, A158; 131

34. Schafer J, Schnarchen, Schlafapnoe und obere Luftwege. Stuttgard, New York: Thieme, 1996, 33-180.

35. Feneis H. Antomisches Bilderworterbuch. Stuttgard, New York:Thieme, 1988: $114-117$

36. Riu R, Guillerm R, Majer EH, Naummann HH et al. La muquese nasale et ses problems. In: Pflatz CR (Hrsg). Forum medichi. Balc: Zyma S.A. $1978 ; 12-43$

37. Freche C, Fontanel JP, et al. Rhonchopatie et obstruction nasale: L obstruction nasale. Rapport de la Societe francaise d ORL. Paris: Arnette Blackwel, 1996: 285-290

38. Вичева Д. "Ринити" 2004, 35-45

39. Вичева Д., Хойзинг. "Хирургична анатомия и основи дисекционни техники на носа", 2003, 13-18 